\title{
Reuse of treated wastewater in viticulture: Can it be an alternative source of nutrient-rich water?
}

\author{
F. Etchebarne ${ }^{1}$, P. Aveni ${ }^{2,}$ a , J.-L. Escudier ${ }^{2}$, and H. Ojeda ${ }^{2}$ \\ ${ }^{1}$ Independent Scientist, 11560, Saint Pierre la Mer, France \\ ${ }^{2}$ UE PECH-ROUGE, INRA, Université de Montpellier, CIRAD, Montpellier SupAgro, 11430, Gruissan, France
}

\begin{abstract}
Water scarcity is a global problem, which leads to unprecedented pressure on water supply in arid and semi-arid regions. Treating wastewater is an alternative and valuable water resource, therefore its reuse for agricultural irrigation has been growing worldwide since the beginning of the $21^{\text {st }}$ century. In several regions of the wine-producing countries subject to significant water stress (e.g., Australia, California-USA, Spain), wastewater recycling appears to be the most accessible alternative, both financially and technically, for the agricultural uses that notably not requiring drinking water. Therefore, this research was planned to quantify the contribution of treated wastewater (TWW) to fertilization-needs of the vine, evaluate the impact of irrigation with TWW on the soil, vegetative growth, yield, and wine and grape juice composition. The results provide scientific and technical knowledge on a strategy of water management with high added value. The fertilizer contribution of the TWW would be important, according to the plant's nutrient needs (e.g., in this study 19-39 Unit N, 0.5-1.1 Unit P and 14-28 Unit $\mathrm{K} \mathrm{ha}^{-1}$ were supplied with TWW). Ensuring treated wastewater microbiological quality is essential, but without reducing of its nutrients. These nutrients would be a valuable input for crop growth and yield, and could reduce the need to resort for inorganic/synthetic fertilizers. A sustainable use of treated wastewater over the long term would, however, necessitate a good practice guidelines and an integrated vision of treated wastewater quality, crops, irrigation and post-harvest practices.
\end{abstract}

\section{Introduction}

The increase in drought due to climate change, mainly in arid and semi-arid areas, leads to unprecedented pressure on water supply worldwide. Treated wastewater is an alternative and valuable resource. Its use for agricultural irrigation is in continuous growth around the world since the beginning of the $21^{\text {st }}$ century [1-6]. Nowadays, many countries consider this practice as an important alternative local water resource. This leads to a growing awareness of the value of treated wastewater, including the nutrients it contains $[5,6]$.

In several regions of the wine-producing countries subject to significant water stress, wastewater recycling appears to be the most accessible alternative, both financially and technically, for the agricultural uses that notably not requiring drinking water [8]. In Europe, the reuse of treated wastewater (TWW) contributes to the implementation of the water framework directive (European Directive 2000/60/EC) by enabling sustainable management of the resource. In France, the development of the TWW reuse is encouraged by the Grenelle of the Environment (Law Grenelle I).

The extent at which wastewater has to be treated prior to irrigation depends on the restrictions established in local or international water quality criteria for irrigation [10]. The production of recycled water for agriculture is regulated in France by the ANSES - French Agency for Food, Environmental and Occupational Health \&

\footnotetext{
${ }^{a}$ Intern student.
}

Safety, according to parameters from the French decree of 25 June 2014 (NOR: AFSP1410752A). Depuration of wastewater prior to its reuse is the most plausible option to prevent soil pollution from wastewater reuse. However, since wastewater represents a cheap source of water and fertilizer for farmers [10], it is necessary to consider the needs of users before planning schemes of wastewater treatment. Treating wastewater by simple treatment systems may be an opportunity to couple sanitation with reuse within a program of comprehensive management of wastewater, the recycling of nutrients and the use of soil as a food producer and purification system.

Irrigation of vineyards and other crops with TWW is currently practiced in several countries, and many field experiences have shown advantages over the production and quality of the grapes [11-20]. While others have shown that it could increase soil salinity, alter vine nutrient uptake and reduce wine quality [18]. Although the high salt content, often characterizing recycled water, can influence plant response $[18,21,22]$, it is heavily dependent on nutrient availability and salt type [23]. Moreover, given that most agricultural wastewater irrigation is performed using municipal wastewater, which contains negligible amounts of heavy metals [24], the occurrence of these elements in wastewater irrigated soils is usually significantly lower than the maximum permissible concentrations established by international regulations [25].

Water quality and availability are not the only factors that should be considered, improving the efficiency of 
water use may be more important. In France, the technical feasibility of the TWW reuse has been shown, at the level of the water quality according to French regulations (NOR: AFSP1410752A) [27], as the reasoned water use in grapevine drip irrigation [26,28-30]. From the analysed microbiological and physicochemical parameters, neither disadvantage nor change associated with the TWW reuse practice was observed on the short-term on the integrated system wine-grapevine-groundwater-soil-water. During the three years of research, the nutritional status of plant and the composition of wine and fruit showed more sensibility to the vintage year than to the quality of the supplied water $[29,30]$. Therefore, the combined effect of different irrigation levels and water quality on vegetative growth and yield of grapevines should be considered.

This study sought to avoid rejecting recycled and nutrient-loaded water into the natural environment, while in agriculture they could be benefit plants and partially replace the use of inorganic/synthetic fertilizers. In any case, this was the hypothesis formulated within the framework of this project. In order to answer a question of major interest which has not yet been well studied, and this is linked to the advantages and disadvantages of fertigation by the TWW (urban origin) in grapevine. While assessing potential risks to soil, plant, fruit and wine.

Therefore, this study was planned to (i) quantify the contribution of treated wastewater (TWW) to fertilizationneeds of the vine (ii) evaluate the impact of irrigation with TWW on the physicochemical properties of the soil, and (iii) deeper understand the effect of irrigation with TWW on the vegetative growth and yield of vine, and on the chemical composition of grape juice and wine.

\section{Material and methods}

\subsection{Experimental site and treatments}

This study was conducted at INRA UE Pech Rouge in Gruissan, France (latitude $43^{\circ} 08^{\prime} 35^{\prime \prime} \mathrm{N}$; longitude $3^{\circ} 7^{\prime} 59^{\prime \prime}$ ), in two experimental vineyards using "Viognier B" grafted onto $\mathrm{SO}_{4}$ rootstock in a sandy loam soil (planted in 1996) and "Carignan N" on R110 rootstock in a limestone soil (planted in 1983). The region has a Mediterranean climate and annual rainfall of approximately $550 \mathrm{~mm}$. Both vineyards were planted at a spacing of $1 \mathrm{~m} \times 2.5 \mathrm{~m}$, with a northwest-southeast orientation. "Viognier B" vineyard is cultivated on cane-trained system (single Guyot prunning) with a three-wire VSP trellis system and "Carignan N" on spur-trained system with a canopy free trellis goblet system.

The experimental plot consisted of four rows adjacent to each other (strip plot design), for each irrigation treatment (with two buffer vine rows without irrigation between each treatment) which were divided into three blocks (with buffer vines at the start and end of each row), each considered as field replicates. The experimental plots were irrigated with two different water sources, which correspond to treatment plots: drinking water $(\mathrm{DW}=$ control $)$ and treated wastewater quality C (TWW$\mathrm{C}=$ tertiary treatment with filtration, disinfection UV and chlorine injection). In addition, two irrigations levels were applied for each type of water, which correspond to treatment subplots: standard $(1=$ based on measures of vine water status $\left(\Psi_{\mathrm{pd}}\right)$, from berries pea-size) and reinforced $(2=$ starting after budburst, at flowering, then based on measures of vine water status with reinforced at veraison and postharvest irrigation).

\subsection{Irrigation management}

Irrigation was applied via drippers with a delivery rate of $1.6 \mathrm{~mm} \mathrm{~h}^{-1}$ (drip lines spaced $1 \mathrm{~m}$ apart), and from berries pea-size (E-L stage 31) [31] monitored by measurement of plant water status, according to a leaf water potentialbased model for vine irrigation strategies adapted to white and red wine production [32]. Measurements of predawn leaf water potential $\left(\Psi_{\mathrm{pd}}\right)$ were taken every 14 days (between 3:00 and 5:00) - according to climate conditions and the phenological growth stages - on the same grapevines selected for vegetative growth measurements at the phenological stage of inflorescence well developed (E-L stage 17) [31]. Only healthy and mature leaves were measured with a pressure chamber (Plant Water Status Console 3000, Soilmoisture Inc., Santa Barbara, CA, USA). Irrigation started at E-L stage 12 (shoots $10 \mathrm{~cm}$ ) [31] by standard reinforced treatment subplots and E-L stage 31 (berries pea-size) [31] by standard treatment subplots, and was continued until harvest and postharvest, respectively.

\subsection{Monitoring of irrigation water composition}

Samples of TWW-C were collected once a month (from June to August) in sterile $0.5 \mathrm{~L}$ plastic containers and sent to a commercial laboratory for analysis. The chemical oxygen demand (COD), total suspended solids (TSS), electric conductivity (EC) and $\mathrm{pH}$ were measured following the required protocols prescribed for each quality parameter. The Escherichia coli (E. coli), total coliforms, Enterococcus, F-RNA coliphages and Sulphitereducing bacteria (SRB) were analyzed by standardized water analysis methods. Ammonium $\left(\mathrm{NH}_{4}^{+}\right)$, nitrate $\left(\mathrm{NO}_{3}^{-}\right)$, nitrite $\left(\mathrm{NO}_{2}^{-}\right)$, orthophosphate $\left(\mathrm{PO}_{4}^{3-}\right), \mathrm{K}, \mathrm{Ca}, \mathrm{Mg}$, $\mathrm{S}, \mathrm{Na}, \mathrm{Cl}, \mathrm{Fe}, \mathrm{Zn}, \mathrm{B}$ and heavy metals $(\mathrm{Cd}, \mathrm{Cr}, \mathrm{Cu}, \mathrm{Hg}, \mathrm{Ni}$, $\mathrm{Pb}, \mathrm{As}, \mathrm{Al}$ ) were also analyzed.

\subsection{Soil sampling and analysis}

Soil sampling was carried out at postharvest (E-L stage 41) [31]. Fifteen undisturbed samples were collected from the experimental plots (four treatment subplots irrigated compared to one without irrigation) in each vineyard, so three samples from each subplot (at 0-20 cm depth in "Viognier B" and $0-10 \mathrm{~cm}$ in "Carignan N"). Composite samples were prepared by mixing the three samples of the same experimental plot. After removal of roots, grasses and others debris, samples were air-dried in the laboratory and then $500 \mathrm{~g}$ of each sample were sealed in polyethylene bags and sent to a commercial laboratory. Acid-base status ( $\mathrm{pH}$, calcarium, CEC), dry matter, organic carbon, total $\mathrm{N}, \mathrm{C} / \mathrm{N}, \mathrm{N}^{-\mathrm{NH}_{4}}, \mathrm{~N}-\mathrm{NO}^{3}, \mathrm{P}_{2} \mathrm{O}_{5}, \mathrm{~K}_{2} \mathrm{O}, \mathrm{MgO}$, $\mathrm{CaO}$ totals and 7 heavy metals $(\mathrm{Cd}, \mathrm{Cr}, \mathrm{Cu}, \mathrm{Hg}, \mathrm{Ni}, \mathrm{Pb}, \mathrm{Zn})$ of the soil samples were determined following standard methods.

\subsection{Shoot growth measurements}

Shoots $(n=96)$ were tagged at the beginning of the experiment using flagging tape. Six grapevines in each 
of the four treatment subplots irrigated for two cultivars were selected, and 2 shoots per plant were measured. The measures began to take weekly from inflorescence well developed (E-L stage 17) [31] until the point where vegetative growth stopped. Relative shoot elongation was determined by evaluating shoot length with a measuring tape to the nearest centimeter. Relative shoot growth rate (RGR) was estimated using the following formula:

$$
\operatorname{RGR}(\%)=\frac{\left(L_{1}-L_{0}\right)}{L_{1}} \times \frac{100}{t}
$$

Where:

$$
\begin{aligned}
& L_{1}=\text { final shoot length } \\
& L_{0}=\text { initial shoot length } \\
& t=\text { time period in days between } L_{1} \text { and } L_{0} .
\end{aligned}
$$

On post-harvest, the lateral shoots in each of the main shoots were counted and measured. Vine leaf area was assessed by shoots leaf area (main and laterals) and shoots length (model proposed by Mabrouk and Carbonneau 1996) [33]. The linear equation was established at postveraison in each grapevine cultivar, and the total leaf area (LA) per plant for each treatment was estimated using the following equations:

$$
\begin{aligned}
& L A_{v}=12.257 x+72.738+10.271 y+8.0977 \\
& L A_{c}=30.692 x+313.01+21.353 y+3.1879
\end{aligned}
$$

Where:

$$
\begin{aligned}
& { }_{v}=\text { Viognier } \mathrm{B} \\
& c=\text { Carignan } \mathrm{N} \\
& x=\text { main shoot length } \\
& y=\text { average lateral shoots length. }
\end{aligned}
$$

\subsection{Grapevine canes sampling and nutrient reserves analysis}

Pruning mass and canes number data were collected on 30 grapevines per treatment subplot (10 plants per replicate $n=3$ ), and average values were calculated.

Nutrient concentrations and carbohydrate contents in extracts from cane were estimated on three samples from each treatment subplot. Thirty canes were collected from 10 grapevines by replicate $(n=3)$ under each treatment after finish of leaf fall (E-L stage 47) 31 on 14th December 2017 by "Carignan N" and 23rd January 2018 by "Viognier B", for the estimation of nutrient reserves. The canes collected from each sample were combined together and on each cane were removed the first 6 internode sections (without node). Samples were sealed in paper bags and sent to a commercial laboratory for chemical analysis [starch, soluble sugars, total carbohydrates and macronutrients $(\mathrm{N}, \mathrm{P}, \mathrm{K}, \mathrm{Ca}, \mathrm{Mg})]$.

\subsection{Harvest fruit measurements}

One day before harvest, a random sample of 30 bunches were collected from each treatment subplot $(10$ per replicate $n=3$ ). In the laboratory, a subsample of 200 berries removed from the 10 bunches per replicate was weighted - for determination of the average fresh berry mass - and processed for juice analysis.
Total soluble solids (TSS, ${ }^{\circ}$ Brix) were measured using a hand refractometer (Euromex, Holland) with temperature correction. Juice $\mathrm{pH}$ was measured with a benchtop $\mathrm{pH}$ metre (Inolab720, WTW, Germany). Titratable acidity (TA) was measured by titration to $\mathrm{pH} 7\left(20^{\circ} \mathrm{C}\right)$ (Titromatic, Crison, Spain), and the results were expressed in $\mathrm{g} / \mathrm{L}$ sulphuric acid. Malic (M) and tartaric (T) acids were measured by HPLC with spectrophotometry detection at $210 \mathrm{~nm}$ (Waters, USA). Sodium (Na) and potassium (K) were quantified by atomic emission spectroscopy, and magnesium $(\mathrm{Mg})$ and calcium $(\mathrm{Ca})$ by atomic absorption spectroscopy using a spectrometer (Thermo S4 AA system, England). Yeast assimilable nitrogen (YAN) content was measured by photometric analyzer (Gallery, Thermo Fisher Scientific, USA).

Grapevines were harvested by hand, one day after bunch sampling. Yield and bunch number data were collected on 10 grapevines per replicate $(n=3)$, for a total of 30 grapevines per treatment subplot. Average grapevine yield and bunch number were calculated. Bunch fresh mass was determined by dividing the yield of each replicate by the bunch number.

\subsection{Winemaking and assessment}

The harvest was stored at $10^{\circ} \mathrm{C}$ for 24 hours before crushing for red wine making, and also pressing for white wine making. Ten ferments were prepared (four treatment subplot irrigated and one without irrigation, per two grapevine cultivars) and based on $120 \mathrm{~kg}$ of grape. The TSS, $\mathrm{pH}, \mathrm{AT}$ and YAN of the must were measured. $\mathrm{SO}_{2}\left(5 \mathrm{~g} \mathrm{hL}^{-1}\right)$ and diammonium hydrogen orthophosphate (DAP) $\left(20 \mathrm{~g} \mathrm{hL}^{-1}\right.$ only for white wine making) were added to the must. It was inoculated with Fermicru@ LVCB (white wine) and NT 202 (red wine) yeast (Oenobrands SAS, France) at a rate of $20 \mathrm{~g} \mathrm{hL}^{-1}$. The must was fermented at $18-19^{\circ} \mathrm{C}$ (white wine making) and $23-24^{\circ} \mathrm{C}$ on skins with the cap plunged twice a day (red wine making) until the residual sugar fell below $0.5 \mathrm{~g} \mathrm{~L}^{-1}$. Then, in red wine making, the must were pressed and left for finalization of malic fermentation. After racking off the lees, $\mathrm{SO}_{2}$ was added at $5 \mathrm{~g} \mathrm{hL}^{-1}$ and was stored at $10^{\circ} \mathrm{C}$. The wine was cold stabilized by storing at $-6^{\circ} \mathrm{C}$ for 10 days. After stabilization, the wine was racked off the tartrates and the free $\mathrm{SO}_{2}$ was adjusted to $30 \mathrm{mgL}^{-1}$, filtered and bottled under $\mathrm{N}_{2}$ gas. The wine was characterized by measures of alcohol, pH, VA (volatile acid), TA (titratable acidity), juice color (OD 420) in white wine, and total polyphenol index (OD 280) and A (anthocyanin) in red wine. Furthermore, the ion content $(\mathrm{K}, \mathrm{Ca}$, and $\mathrm{Cu})$ in wine were analysed.

\subsection{Statistical analysis}

Statistical analysis was carried out with InfoStat software, student version 2016 (National University of Córdoba, Argentine) for Windows. The possible significant differences among samples according to the different factors considered in this study were established by analysis of variance (ANOVA) and means were separated by Fisher's least significant difference (LSD) test $(p>0.05)$. 


\section{Results and discussion}

Treated wastewater quality results (quality C) confirmed that all parameters complied with French legislation for the irrigation of crops and green spaces (NOR: AFSP1410752A) (data not shown).

\subsection{Irrigation and grapevines water status}

During the 2017 growing season (from April $1^{\text {st }}$ to October $\left.31^{\mathrm{st}}\right) 114.5 \mathrm{~mm}$ of precipitation were recorded by the automatic weather station. The amounts of irrigation water applied to "Viognier B" plot were $50 \mathrm{~mm}$ for the standard irrigation (1) and $92.5 \mathrm{~mm}$ for the reinforced irrigation (2), and to "Carignan N" plot, $45 \mathrm{~mm}$ (1) and $87.5 \mathrm{~mm}$ (2) respectively. The Fig. 1 shows that the evolution of the vine water status would vary according to the volume of water supplied and to the soil water holding capacity. In "Carignan N" plot, the reinforced irrigation (2) treatment subplots were differentiated from the others, after to increasing the volume water supplied at veraison (Fig. 1B). Then, the proximity and crossing of the curves of standard irrigation (1) and non-irrigated (NI) treatment subplots, observed until mid-ripeness, would be suggesting a deep rooting and/or a good tolerance of "Carignan N" to drought, which decreases as the maturation progresses.

\subsection{Fertiliser contribution of treated wastewater}

In order to maintain quality, especially for the wine grape, the grower has to maintain a perfect balance between different fertilising factors responsible for quality. The nutrients supply with TWW used in carefully controlled irrigation at an application rate of 500-925 by "Viognier B" plot and $450-875 \mathrm{~m}^{3} \mathrm{ha}^{-1}$ by "Carignan N" plot in treatments TWW-C1 and TWW-C2, respectively, compared to annual fertilisation needs of grapevine [34] are given in Table 1. Results showed that in addition to the water economic profit, the fertilizer contribution of the TWW would be important, according to the plant's nutrient needs. In general, the fertigation advice for wine grape-expected yield from 5 to $8 \mathrm{~T} \mathrm{ha}^{-1}$ of fruit or 40 to $60 \mathrm{hL} \mathrm{ha}^{-1}-$ comprise 40 Unit $\mathrm{N}, 10$ Unit $\mathrm{P}$ and 60 Unit $\mathrm{Kha}^{-1}$. The TWW contained $\mathrm{N}, \mathrm{P}$ and $\mathrm{K}$ at concentrations of $42,1.2$ and $30 \mathrm{mg} \mathrm{L}^{-1}$ respectively (in growing season 2017), which would contribute 48-98, $5-11$ and $23-47 \%$ of the corresponding supplied nutrients with treated wastewater-irrigated treatments TWW-C1 and TWW-C2, respectively. Efficient nutrient management, in particular $\mathrm{N}$, should be based on meeting the actual $\mathrm{N}$ demand of the vine during the various phenological stages of growth [35]. During bud burst to flowering, for instance, the vast majority of $\mathrm{N}$ used for shoot growth is translocated from permanent structures of the vine and only a small amount is obtained from soils. From fruitset to veraison, however, soil $\mathrm{N}$ is more important and may comprise $65 \%$ of the total crop uptake for a given season [35]. Nitrogen supplied by recycled water during various phenological stages may not adequately match this varied demand for $\mathrm{N}$ when supplies are based on vine water requirements [36]. Plant availability of $\mathrm{N}$ in soils irrigated with recycled water also varies in relation to changes in soil temperature, $\mathrm{pH}$, aeration and water content [18]. Typically, grapevine phosphorus $(\mathrm{P})$ requirements are considerably less than that of other annual crops, and

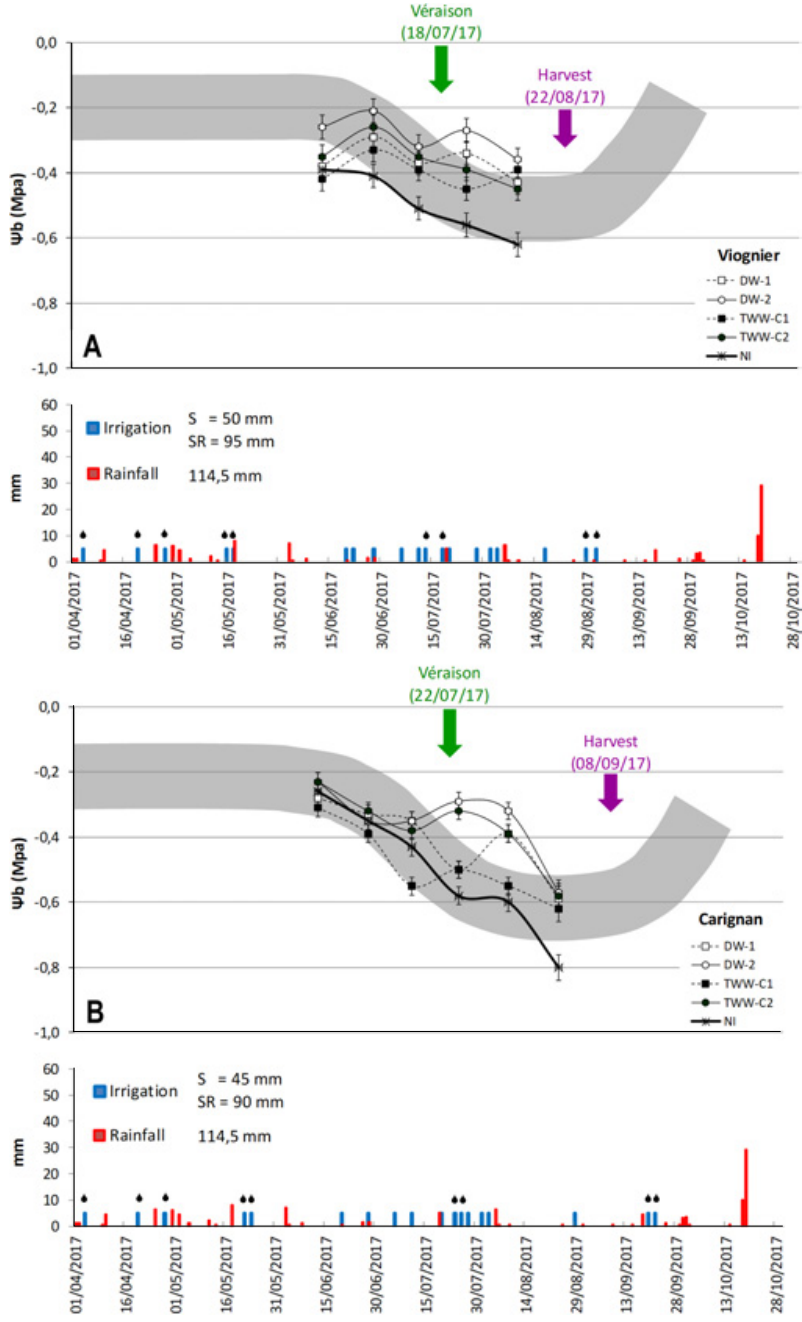

Figure 1. Predawn leaf water potential evolution $\left(\Psi_{\mathrm{pd}}\right)$ Vitis vinifera $\mathrm{L}$ Viognier/SO $\mathrm{SO}_{4}$ (A) and Carignan/R110 (B) during growing season 2017. Each point represents the average of $n=3$ plants and bars indicate the minimal significant differences (LSD test, $p>0.05)$. The grey area indicates the reference values according to a predawn leaf water potential model [32]. Bar graph shows irrigations $\square(\checkmark$ reinforced irrigation, only treatment subplot 2) and rainfall $\square$.

reported deficiencies in vine $\mathrm{P}$ status are rare [37]. Relative to vine $\mathrm{P}$ demand, TWW used in this study was not rich in P $\left(1.2 \mathrm{mg} \mathrm{L}^{-1}\right)$, several studies report sufficient or improved vine $\mathrm{P}$ nutritional status when irrigated with recycled waters $[9,12,36,38]$. Higher mobility of $\mathrm{P}$ in wastewater relative to dry fertilisers also enables greater distribution through the soil profile reaching a higher percentage of actively growing root tips [39]. It was reported greater plant's utilisation of $\mathrm{P}$ in municipal wastewater when applied weekly, than a single application of superphosphate of similar P loading, because of its better mobility in soils and its plant available form [38].

The irrigation with TWW has a degree of similarity to fertigation, but results compared with other studies $[13,14,16,36]$ becomes complicated because the nutrients concentrations and contents would be directly linked to wastewater origin (town-country), as well as to treatment techniques used by wastewater treatment plant. Furthermore, amount water irrigation supplied varies enormously in terms of climatic conditions, especially in 
Table 1. Estimated nutrients supply at an irrigation rate of $500-925$ by Viognier B plot and $450-875 \mathrm{~m}^{3}$ ha $\mathrm{a}^{-1}$ by Carignan $\mathrm{N}$ plot in treatments TWW-C1 and TWW-C2, respectively, in 2017 growing season, compared to annual fertilization needs of grapevine.

\begin{tabular}{|c|c|c|c|c|c|c|}
\hline \multirow{3}{*}{ Parameters } & \multirow{2}{*}{\multicolumn{2}{|c|}{$\begin{array}{l}\text { Viognier } \\
\text { TWW-C }\end{array}$}} & \multicolumn{2}{|c|}{ Carignan } & \multirow{3}{*}{ Annual fertilisation-needs* } & \multirow{3}{*}{ Unit } \\
\hline & & & \multicolumn{2}{|c|}{ TWW-C } & & \\
\hline & 1 & 2 & 1 & 2 & & \\
\hline Total Nitrogen & 21 & 39 & 19 & 37 & $20-70$ & $\mathrm{~kg} \mathrm{~N} \mathrm{ha}^{-1}$ \\
\hline Phosphorus & 0.6 & 1.1 & 0.5 & 1.0 & $3-10$ & $\mathrm{~kg} \mathrm{P} \mathrm{ha}^{-1}$ \\
\hline Potassium & 15 & 28 & 14 & 27 & $25-70$ & $\mathrm{~kg} \mathrm{~K} \mathrm{ha}^{-1}$ \\
\hline Calcium & 45 & 84 & 41 & 79 & $39-80$ & $\mathrm{~kg} \mathrm{Ca} \mathrm{ha}^{-1}$ \\
\hline Magnesium & 11 & 19 & 9 & 18 & $6-15$ & $\mathrm{~kg} \mathrm{Mg} \mathrm{ha}^{-1}$ \\
\hline Sulfate & 25 & 47 & 23 & 44 & 6 & $\mathrm{~kg} \mathrm{~S} \mathrm{ha}^{-1}$ \\
\hline
\end{tabular}

arid or semi-arid regions, and if it is about wine grapes or table grapes. In this study, moreover, the fertigation with TWW provides other nutrients as $\mathrm{Ca}\left(90 \mathrm{mg} \mathrm{L}^{-1}\right)$ and $\mathrm{Mg}\left(21 \mathrm{mg} \mathrm{L}^{-1}\right)$, generally used in foliar fertilization to correcting nutritional deficiencies, as well as $\mathrm{SO}_{4}\left(50 \mathrm{mg} \mathrm{L}^{-1}\right)$. In terms of TWW nutrients concentration (origin urban of Narbonne Plage's wastewater treatment plant), levels had not varied between seasons during the period 2013-2017 [30].

In the case of soils with poor fertility, the application of TWW can, improve crop yield, and the physical properties and fertility of soils [40] by adding nutrients and organic matter [41]. In this study, the results of soil analysis were compared with the threshold values of Annex 1 of the Decree of 8 January 1998, which lays down the technical requirements applicable to the application of sludge on agricultural soils under Decree No. 97-1133 of December 8, 1997 relating to the spreading of the sludge resulting from wastewater treatment. $\mathrm{Na}_{2} \mathrm{O}$ concentrations in the soils of both experimental plots ranged from 0.02 to $0.2 \mathrm{~g} \mathrm{Na}_{2} \mathrm{O} \mathrm{kg}^{-1} \mathrm{DM}$ (dry matter) corresponding to $\mathrm{Na}$ concentrations of 7.5 to $75 \mathrm{mg} \mathrm{kg}^{-1}$ DM. Figure 2 shows a higher $\mathrm{Na}_{2} \mathrm{O}$ content in soils that have received TWW, probably related to salt water inflows into urban wastewater collection systems. The desirable $\mathrm{Na}_{2} \mathrm{O}$ concentration is $<0.1 \mathrm{~g} \mathrm{~kg}^{-1}$, which is exceeded in TWW-C1 and TWW-C2 treatments by "Viognier B" plot (Fig. 2A) and TWW-C2 by "Carignan N" plot (Fig. 2B). In this case, although $\mathrm{Na}_{2} \mathrm{O}$ concentrations in soils before started this study (in 2013) were between 0.14-0.21 and $0.1-0.16 \mathrm{~g} \mathrm{~kg}^{-1}$ for "Viognier B" and "Carignan N" plots, respectively, thus 2017 results show a tendency of concentration on soils irrigated with TWW-C and decrease on DW treatments subplots. It should be noted that between the last irrigation and soil sampling, no rain was recorded for "Viognier B" plot; but low rainfall (5.5 $\mathrm{mm}$ in total) was recorded during this time interval for "Carignan N" plot. Soils with high Na concentration may result in preferential uptake of $\mathrm{Na}$ at the expense of $\mathrm{Ca}$ and $\mathrm{Mg}$ that can lead to nutrient deficiencies in the vine $[9,42]$. Thereby, it will be necessary monitoring these parameters and possible grapevine deficiencies over the growing season. Monovalent ions applied with wastewater may have confounding effects on soils beyond that imposed by salinity alone. The divalent cations $\mathrm{Ca}$ and, to a lesser extent, $\mathrm{Mg}$ contribute to the structural stability of soils. When the concentration of monovalent cations in the soil solution is high, however, divalent cations are readily displaced from the soil surface, resulting in a reduction in soil stability $[43,44]$. However, for a given sodium
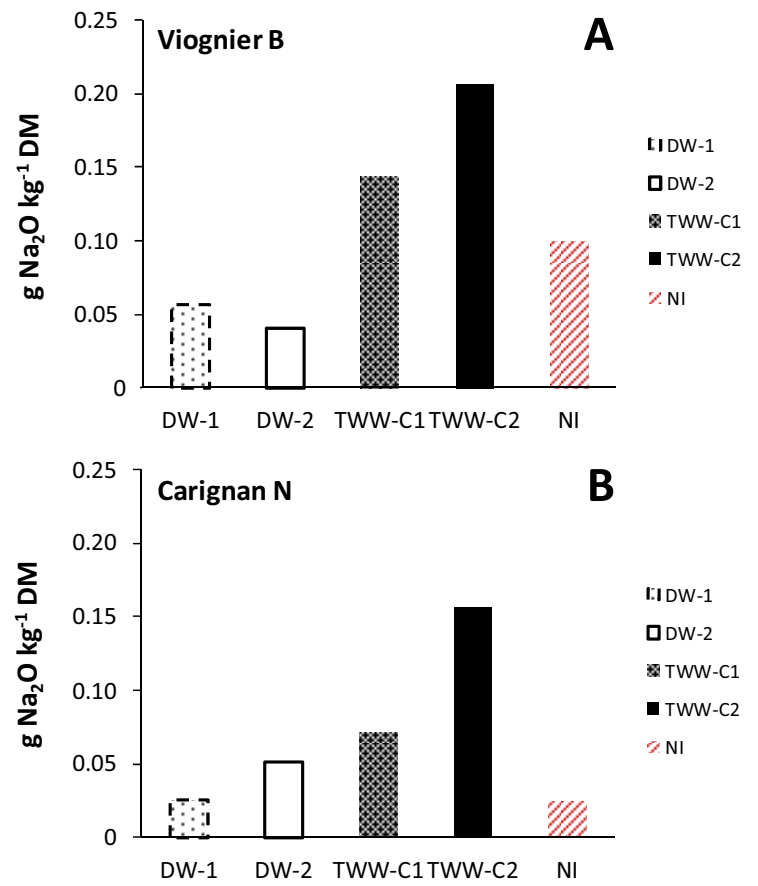

Figure 2. Sodium concentrations $\left(\mathrm{Na}_{2} \mathrm{O} \mathrm{g} \mathrm{kg}{ }^{-1}\right)$ in soil samples from Viognier B (A) and Carignan N (B) plots at postharvest, in growing season 2017.

adsorption ratio (RAS), the rate of infiltration increases with certain conditions, such as salinity in particular. The RAS and the electrical conductivity of irrigation water $(\mathrm{ECW})$ should therefore be used in combination to assess potential risks. According to the FAO guidelines for the interpretation of water quality for agriculture with a RAS $=3-6$ and an ECw $>1.2 \mathrm{dS} \mathrm{m}^{-1}$, there will be no problem of permeability, nor a reduction of infiltration rate in the soil [45]. In this study, TWW had an average RAS of 3 and an ECw of $1.4 \mathrm{dS} \mathrm{m}^{-1}$.

For all other parameters [water $\mathrm{pH}$, total limestone, cation exchange capacity (CEC), calcium, phosphate, potassium, magnesium, organic matter, $\mathrm{C} / \mathrm{N}$ ratio and nitrogen balance (ammonia, nitrate and total nitrogen)] measured in soils, the results did not showed differences between treatments neither compared to recorded data before started this study in 2013 (data not shown). Drip irrigation was carefully controlled, based on vine water requirements at a low volume $\left(50 \mathrm{~m}^{3} \mathrm{ha}^{-1}\right)$ supplied once a week. It was reported that irrigation can adversely affect soil structure, in particular under drip irrigation when localized and highly frequent application of large volumes 

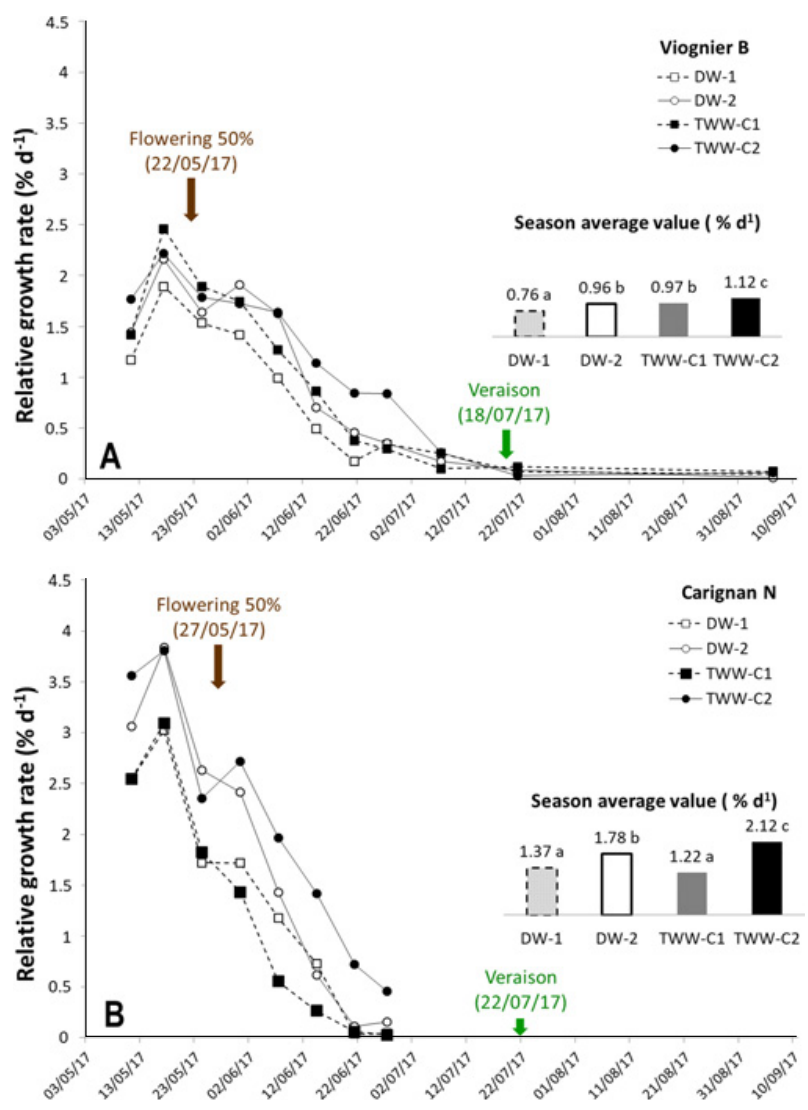

Figure 3. Relative growth rates (RGR) for Viognier B (A) and Carignan $\mathrm{N}$ (B) vines irrigated with treated wastewater quality C (TWW-C) and drinking water (DW), during 2017 growing season. Each point represents the average of $n=12$ shoots. Bar graph shows average value over growing season and different letters indicate a significant difference at $p>0.05$ (LSD test).

of water lowers soil strength and promotes a breakdown in soil structure [46]. The present study highlights the fact that proper handling of drip irrigation is essential to reduce environmental and health risks particularly when TWW is reused for the irrigation of perennial crops as grapevine.

\subsection{Growth and yield attributes of grapevine}

Relative shoot growth rate (RGR) had its highest point at begin flowering, for both cultivars and then began to decrease until veraison (Fig. 3). At the start of the measures, the RGR was approximately $1.3 \% \mathrm{~d}^{-1}$ for the DW-1, DW-2 and TWW-C1 treatment subplots, and $1.8 \% \mathrm{~d}^{-1}$ for TWW-C2 in "Viognier B" vines (Fig. 3A); for "Carignan N" vines the RGR was approximately $2.5 \% \mathrm{~d}^{-1}$ by DW-1 and TWW1, and 3.3\% by DW-2 and TWW-C2 treatment subplots (Fig. 3B). Shoot growth stopped by the end of July in "Viognier B" vines, while that in "Carignan $\mathrm{N}$ " was not possible to continue taking measures from the end of June due to the spring mechanical pruning practice on goblet system. By that time, however, shoot growth in the most treatments subplots was already being stopped, while growth was still observed (approx. $0.5 \% \mathrm{~d}^{-1}$ ) in the TWW-C2 treatment subplot. Relative growth rates were significantly greater $(p>0.05)$ from mid-June until July for "Viognier B" and from June until the last measurement for "Carignan N", in TWW-C2 treatment vines compared to others irrigation treatments (Fig. 3). Similar results

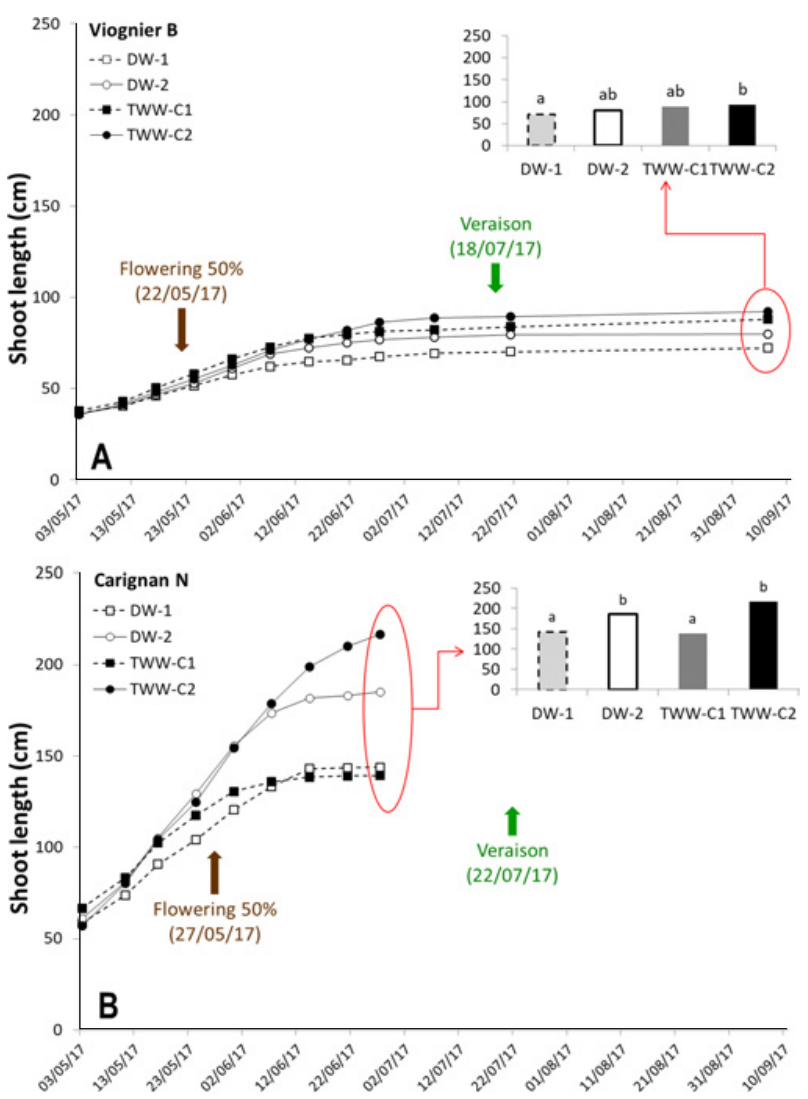

Figure 4. The effect of water quality (TWW-C, treated wastewater quality $\mathrm{C}$ and DW, drinking water) and volume water supplied by drip irrigation (1, standard and 2, reinforced) on average main shoot length during growing season 2017. For Viognier B (A) and Carignan N (B) vines. Each point represents the average of $n=12$ shoots. Bar graph shows last measure and different letters indicate a significant difference at $p<0.05$ (LSD test).

were also obtained in Baja California, Mexico where vine received larger volumes of TWW (equivalent to $264 \mathrm{~m}^{3} \mathrm{ha}^{-1}$ per week) [16]. Treated wastewater played a substantial role in the RGR, and the variation of its quantity in irrigation applied to some strategic phenological states, caused significant difference compared to the irrigation with drinking water (Fig. 3).

The vines irrigated with TWW grew faster than plants irrigated with DW, and the level of irrigation had a significant effect on shoot growth in "Carignan N" plot, during the course of the experiment (Fig. 4). This could be associated with the higher concentration of total nitrogen in the TWW, and probably to the soil water holding capacity. In "Viognier B" plot, irrigating with DW at different volume supplied (500 and $925 \mathrm{~m}^{3} \mathrm{ha}^{-1}$ ) had not a dramatic effect on shoot growth compared with those irrigated with TWW (Fig. 4A). However, in "Carignan N" plot, vine irrigated at $875 \mathrm{~m}^{3} \mathrm{ha}^{-1}$ increased shoot lengths faster compared with those irrigated at $400 \mathrm{~m}^{3} \mathrm{ha}^{-1}$ regardless of water quality (Fig. 4B). In general, the moderate to high salinity of the TWW $\left(\mathrm{EC} 1.4 \mathrm{dSm}^{-1}\right)$ did not appear to produce any adverse effect on the vegetative growth, compared to vines irrigated with DW. Water quality and quantity affected grapevine growth and development. However, the final effect of irrigation on shoots length (Fig. 4), leaf area and yield components 
Table 2. Vegetative growth and yield components recorded on Viognier B and Carignan N grapevines during growing season 2017.

\begin{tabular}{|c|c|c|c|c|c|c|c|c|c|}
\hline & Treatment & $\begin{array}{c}\text { Total } \\
\text { LA/vine } \\
\left(\mathrm{cm}^{2}\right)\end{array}$ & $\begin{array}{c}\text { Shoots/ } \\
\text { vine }\end{array}$ & $\begin{array}{c}\text { Primary } \\
\text { LA/vine } \\
\left(\mathrm{cm}^{2}\right)\end{array}$ & $\begin{array}{c}\text { Lateral } \\
\text { LA/vine } \\
\left(\mathrm{cm}^{2}\right)\end{array}$ & $\begin{array}{c}\text { Yield/vine } \\
\text { (kg) }\end{array}$ & $\begin{array}{c}\text { Brunches/ } \\
\text { vine }\end{array}$ & $\begin{array}{c}\text { Bunch } \\
\text { mass (g) }\end{array}$ & $\begin{array}{c}\text { Berry } \\
\text { mass (g) }\end{array}$ \\
\hline \multicolumn{10}{|l|}{ Viognier B } \\
\hline & DW-1 & $7036 \mathrm{a}$ & 7 & $957 \mathrm{a}$ & $49 \mathrm{a}$ & $1.32 \mathrm{~b}$ & 8 & $165 \mathrm{~b}$ & $1.03 \mathrm{ab}$ \\
\hline & DW-2 & $7696 \mathrm{ab}$ & 7 & $1053 \mathrm{ab}$ & $46 \mathrm{a}$ & $1.25 \mathrm{~b}$ & 8 & $156 \mathrm{~b}$ & $1.12 \mathrm{bc}$ \\
\hline & TWW-C1 & $8461 \mathrm{ab}$ & 7 & $1151 \mathrm{ab}$ & $57 \mathrm{ab}$ & $1.38 \mathrm{~b}$ & 8 & $173 \mathrm{bc}$ & $1.14 \mathrm{bc}$ \\
\hline & TWW-C2 & $8911 b$ & 7 & $1204 \mathrm{~b}$ & $69 \mathrm{~b}$ & $1.51 \mathrm{~b}$ & 8 & $189 \mathrm{c}$ & $1.24 \mathrm{c}$ \\
\hline & NI & nd & nd & nd & nd & $1.00 \mathrm{a}$ & 8 & $125 \mathrm{a}$ & $0.93 \mathrm{a}$ \\
\hline & Sig. & $*$ & ns & $*$ & $*$ & $*$ & ns & $*$ & $*$ \\
\hline \multicolumn{10}{|l|}{ Carignan $\mathbf{N}$} \\
\hline & DW-1 & $44084 \mathrm{a}$ & 9 & $4722 \mathrm{a}$ & $176 \mathrm{a}$ & $1.68 \mathrm{a}$ & 9 & $187 \mathrm{a}$ & 2.18 \\
\hline & DW-2 & $54342 \mathrm{ab}$ & 9 & $5875 \mathrm{ab}$ & $163 \mathrm{a}$ & $1.71 \mathrm{a}$ & 9 & $190 \mathrm{a}$ & 2.16 \\
\hline & TWW-C1 & $42621 \mathrm{a}$ & 9 & 4589 a & $146 \mathrm{a}$ & $2.21 \mathrm{a}$ & 9 & $245 \mathrm{a}$ & 2.00 \\
\hline & TWW-C2 & $66263 \mathrm{~b}$ & 9 & $6963 \mathrm{~b}$ & $400 \mathrm{~b}$ & $2.83 \mathrm{~b}$ & 9 & $314 b$ & 2.20 \\
\hline & NI & nd & nd & nd & nd & $2.04 \mathrm{a}$ & 9 & $227 \mathrm{a}$ & 2.06 \\
\hline & Sig. & $*$ & ns & $*$ & $*$ & & ns & $*$ & ns \\
\hline
\end{tabular}

Data are means of each treatment. Each value represents $n=6$ for LA/vine; $n=12$ for LA/shoot; 30 for yield/vine, bunches/vine and brunch mass; and $n=600$ for berry mass by each treatment. Different letters within columns for each grapevine indicate a significant difference at $p<0.05$ (LSD test). $*$ Denote a significant difference between treatments. LA, leaf area; ns, not significant; nd, not determined; DW, drinking water; TWW-C treated wastewater quality C; NI, non-irrigated; 1 , standard irrigation; 2 , reinforced irrigation.

Table 3. Total carbohydrates and macronutrients concentration in pruned wood recorded on Viognier B and Carignan $\mathrm{N}$ grapevines in growing season 2017.

\begin{tabular}{|c|c|c|c|c|c|c|c|c|c|}
\hline & \multirow[t]{2}{*}{ Treatment } & \multicolumn{2}{|c|}{ Pruning mass } & \multirow{2}{*}{$\begin{array}{l}\text { Total carbohydrates }(\text { starch }+ \\
\text { soluble sugars) }(\mathrm{kg} / \mathrm{ha})\end{array}$} & \multicolumn{5}{|c|}{ Macro-nutrients (kg/ha) } \\
\hline & & (Kg/vine) & (Kg/ha) & & $\mathbf{N}$ & $\mathbf{P}$ & $\mathbf{K}$ & $\mathrm{Ca}$ & Mg \\
\hline \multicolumn{10}{|l|}{ Viognier B } \\
\hline & DW-1 & $0.08 \mathrm{a}$ & $324 \mathrm{a}$ & $47 \mathrm{~b}$ & $3.22 \mathrm{~b}$ & $0.39 \mathrm{~b}$ & $1.93 \mathrm{~b}$ & $2.03 \mathrm{ab}$ & $0.30 \mathrm{ab}$ \\
\hline & DW-2 & $0.13 \mathrm{~b}$ & $528 \mathrm{~b}$ & $81 \mathrm{~d}$ & $4.45 \mathrm{c}$ & $0.53 \mathrm{c}$ & $3.38 \mathrm{~d}$ & $2.60 \mathrm{~b}$ & $0.39 \mathrm{bc}$ \\
\hline & TWW-C1 & $0.12 \mathrm{~b}$ & $488 \mathrm{~b}$ & $73 \mathrm{c}$ & $4.41 \mathrm{c}$ & $0.49 \mathrm{c}$ & $2.77 \mathrm{c}$ & $2.65 \mathrm{bc}$ & $0.46 \mathrm{~cd}$ \\
\hline & TWW-C2 & $0.14 \mathrm{bc}$ & 572 bc & $86 \mathrm{e}$ & $5.01 \mathrm{~d}$ & $0.57 \mathrm{c}$ & $3.47 \mathrm{~d}$ & $3.32 \mathrm{c}$ & $0.53 \mathrm{~d}$ \\
\hline & $\mathrm{NI}$ & $0.06 \mathrm{a}$ & $256 \mathrm{a}$ & $38 \mathrm{a}$ & $2.49 \mathrm{a}$ & $0.29 \mathrm{a}$ & $1.35 \mathrm{a}$ & $1.53 \mathrm{a}$ & $0.25 \mathrm{a}$ \\
\hline & Sig. & $*$ & $*$ & $*$ & $*$ & $*$ & $*$ & $*$ & $*$ \\
\hline \multicolumn{10}{|l|}{ Carignan N } \\
\hline & DW-1 & $0.50 \mathrm{a}$ & 2016 a & $259 \mathrm{~b}$ & $11 \mathrm{a}$ & $1.75 \mathrm{a}$ & $10 \mathrm{a}$ & $9 \mathrm{a}$ & $1.68 \mathrm{a}$ \\
\hline & DW-2 & $0.64 \mathrm{~b}$ & $2560 \mathrm{~b}$ & $320 \mathrm{c}$ & $15 \mathrm{~b}$ & $2.39 \mathrm{bc}$ & $14 \mathrm{~b}$ & $11 \mathrm{~b}$ & $2.05 \mathrm{~b}$ \\
\hline & TWW-1 & $0.61 \mathrm{~b}$ & 2452 b & $257 \mathrm{~b}$ & $18 \mathrm{~b}$ & $2.37 \mathrm{~b}$ & $15 \mathrm{~b}$ & $10 \mathrm{ab}$ & $2.04 \mathrm{~b}$ \\
\hline & TWW-2 & $0.75 \mathrm{c}$ & $2988 \mathrm{c}$ & $374 \mathrm{~d}$ & $20 \mathrm{c}$ & $2.69 \mathrm{c}$ & $18 \mathrm{c}$ & $13 \mathrm{c}$ & $2.39 \mathrm{c}$ \\
\hline & NI & $0.48 \mathrm{a}$ & $1912 \mathrm{a}$ & $210 \mathrm{a}$ & $13 \mathrm{a}$ & $1.59 \mathrm{a}$ & $9 \mathrm{a}$ & $9 \mathrm{a}$ & $1.72 \mathrm{a}$ \\
\hline & Sig. & * & $*$ & $*$ & * & * & * & $*$ & * \\
\hline
\end{tabular}

Data are means of each treatment. Each value represents $n=30$ and 10 by treatment for pruning mass and nutrients content, respectively. Different letters within columns for each grapevine indicate a significant difference at $p>0.05$ (LSD test). *Denote a significant difference between treatments. LA, leaf area; ns, not significant; nd, not determined; DW, drinking water; TWW-C treated wastewater quality C; NI, non-irrigated; 1, standard irrigation; 2, reinforced irrigation.

(Table 2) varied from an experimental vineyard to another, probably due to differences in the degree of water status between treatment subplots (Fig. 1), vine vigour and availability of reserves. Water quality interacted with irrigation level such that the response of leaf area to irrigation was more when TWW was used, and exerted a significant impact on leaf area (and growth) of lateral shoots, and yield only for "Carignan N" (Table 2). The competition between growing tips and fruits may have stimulated the direction of assimilates to shoots [47] and inhibited a significant berries growth at higher rates of irrigation. On the other hand, it has reported irrigating with recycled water suppressed grapevine growth and yield components [13]. Their adverse effects were due to increased salts (EC $1.9 \mathrm{dS} \mathrm{m}^{-1}$ ) and low nitrogen content (10.2 $\left.\mathrm{mg} \mathrm{L} \mathrm{L}^{-1} \mathrm{~N}\right)$ [13], comparing to higher nitrogen content $\left(42 \mathrm{mg} \mathrm{L}^{-1} \mathrm{~N}\right)$ and lower salinity $\left(\mathrm{EC} 1.4 \mathrm{dS} \mathrm{m}^{-1}\right)$ in TWW used in this study. In both grapevines there was an effect of the irrigation compared to plants non-irrigated - by the quantity and quality water (in this order) - on cane pruning mass and nutrient reserves accumulation (Table 3 ). The values estimated by hectare shows well this difference, which would be linked to the effect on canes vigour. Nutrient reserves content decreased notably in the grapevines without irrigation. The higher dose of TWW boosted significantly the vigour of vine.

The lowest pruning mass (256 and $1912 \mathrm{~kg} \mathrm{ha}^{-1}$ for "Viognier B" and "Carignan N", respectively) was in the non-irrigated treatment, and the highest (572 and $2988 \mathrm{~kg} \mathrm{ha}^{-1}$ for "Viognier B" and "Carignan N", respectively) was in the treated wastewater-reinforced irrigation treatment. Water quantity and TWW played a considerable role in increasing the nutrients mobility from soil to the plant, as well as the carbohydrate reserves accumulation (Table 3). Under both irrigation levels (standard and reinforced), vine used water the least effectively in drinking water-irrigation (DW) and most effectively in treated wastewater-irrigation 
Table 4. Juice composition at harvest recorded on Viognier B and Carignan N grapevines irrigated with treated wastewater and drinking water, and compared to a bloc not-irrigated in growing season 2017.

\begin{tabular}{|c|c|c|c|c|c|c|c|c|c|c|c|}
\hline & Treatment & $\begin{array}{c}\text { TSS } \\
\text { (Brix) } \\
(\mathrm{g} / \mathrm{L})\end{array}$ & pH & $\begin{array}{c}\text { Titratable } \\
\text { acidity } \\
\text { (g H2SO4/L) }\end{array}$ & $\begin{array}{c}\text { Tartaric } \\
\text { acid } \\
(\mathrm{g} / \mathrm{L})\end{array}$ & $\begin{array}{l}\text { Malic } \\
\text { acid } \\
(\mathrm{g} / \mathrm{L})\end{array}$ & $\begin{array}{c}\text { YAN } \\
(\mathrm{mg} / \mathrm{L})\end{array}$ & $\begin{array}{c}\mathrm{Na} \\
(\mathrm{mg} / \mathrm{L})\end{array}$ & $\begin{array}{c}\mathrm{K} \\
(\mathrm{mg} / \mathrm{L})\end{array}$ & $\begin{array}{c}\mathrm{Mg} \\
(\mathrm{mg} / \mathrm{L})\end{array}$ & $\begin{array}{c}\mathrm{Ca} \\
(\mathrm{mg} / \mathrm{L})\end{array}$ \\
\hline \multicolumn{12}{|l|}{ Viognier B } \\
\hline & DW-1 & $25.6 \mathrm{ab}$ & $3.36 \mathrm{~b}$ & $3.88 \mathrm{ab}$ & $7.58 \mathrm{bc}$ & $2.48 \mathrm{~b}$ & $71 \mathrm{ab}$ & $38 \mathrm{ab}$ & 1932 & $88 \mathrm{~b}$ & 130 \\
\hline & DW-2 & $26.3 \mathrm{~b}$ & $3.36 \mathrm{~b}$ & $3.68 \mathrm{a}$ & $7.00 \mathrm{a}$ & $2.50 \mathrm{~b}$ & $56 \mathrm{a}$ & $17 \mathrm{a}$ & 1825 & $84 a b$ & 113 \\
\hline & TWW-C1 & $23.4 \mathrm{a}$ & $3.31 \mathrm{~b}$ & $3.98 \mathrm{~b}$ & $7.30 \mathrm{ab}$ & $2.51 \mathrm{~b}$ & $109 \mathrm{bc}$ & $28 \mathrm{ab}$ & 1734 & $70 a b$ & 105 \\
\hline & TWW-C2 & $25.7 \mathrm{ab}$ & $3.38 \mathrm{~b}$ & $3.84 \mathrm{ab}$ & $7.59 \mathrm{bc}$ & $2.39 \mathrm{~b}$ & $115 \mathrm{c}$ & $31 \mathrm{ab}$ & 1960 & $83 a b$ & 109 \\
\hline & NI & $25.2 \mathrm{ab}$ & $3.20 \mathrm{a}$ & $4.01 \mathrm{~b}$ & $7.99 \mathrm{c}$ & $1.81 \mathrm{a}$ & $40 \mathrm{a}$ & $49 \mathrm{~b}$ & 1746 & $66 \mathrm{a}$ & 107 \\
\hline & Sig. & $*$ & $*$ & $*$ & $*$ & $*$ & $*$ & $*$ & ns & $*$ & ns \\
\hline \multicolumn{12}{|l|}{ Carignan N } \\
\hline & DW-1 & 24.1 & $3.36 \mathrm{ab}$ & $3.70 \mathrm{ab}$ & $7.02 \mathrm{ab}$ & $2.35 \mathrm{a}$ & $48 \mathrm{a}$ & $38 \mathrm{a}$ & $1845 \mathrm{a}$ & 63 & 65 \\
\hline & DW-2 & 23.7 & $3.36 \mathrm{ab}$ & $3.55 \mathrm{a}$ & $6.78 \mathrm{a}$ & $2.38 \mathrm{a}$ & $59 \mathrm{a}$ & $44 \mathrm{ab}$ & $1914 \mathrm{a}$ & 53 & 58 \\
\hline & TWW-C1 & 24.3 & $3.43 \mathrm{~b}$ & $3.62 \mathrm{a}$ & $7.36 \mathrm{ab}$ & $2.46 \mathrm{a}$ & $52 \mathrm{a}$ & $51 a b c$ & $2148 \mathrm{~b}$ & 66 & 88 \\
\hline & TWW-C2 & 23.9 & $3.38 \mathrm{ab}$ & $4.11 \mathrm{~b}$ & $7.27 \mathrm{ab}$ & $3.03 \mathrm{~b}$ & $79 \mathrm{~b}$ & $60 \mathrm{c}$ & $2017 \mathrm{ab}$ & 53 & 60 \\
\hline & NI & 24.4 & $3.31 \mathrm{a}$ & $3.96 \mathrm{ab}$ & $7.67 \mathrm{~b}$ & $2.33 \mathrm{a}$ & $67 \mathrm{ab}$ & $54 \mathrm{bc}$ & $1982 \mathrm{ab}$ & 55 & 52 \\
\hline & Sig. & $\mathrm{ns}$ & $*$ & $*$ & $*$ & $*$ & $*$ & * & $*$ & $\mathrm{~ns}$ & $\mathrm{~ns}$ \\
\hline
\end{tabular}

Data are means of each treatment. Each value represents $n=3$ for treatment. Different letters within columns for each grapevine indicate a significant difference at $p>0.05$ (LSD test). *Denote a significant difference between treatments. TSS, total soluble solids; YAN, yeast assimilable nitrogen; ns, not significant; DW, drinking water; TWW-C treated wastewater quality C; NI, non-irrigated; 1, standard irrigation; 2, reinforced irrigation.

(TWW-C). Both treatments received the same amount of irrigation water, regarding the level of irrigation (1 or 2), so it would be the water quality that would have played a key role in increasing the biomass production and nutrient reserves accumulation, significantly, thus increasing the water use efficiency. The greater effectiveness of treated wastewater-irrigated treatments would suggest the possibility of reducing fertilizer doses under irrigation with this water source.

\subsection{Chemical composition of grape juice and wine}

Overall, results confirm that the water quality did not affect both yield (Table 2) and grape juice quality (Table 4). Juice $\mathrm{pH}$ and malic acid were significantly lower in vines non-irrigated. Increasing irrigation level with TWW increased yeast assimilable nitrogen (YAN), however, the YAN concentration in juice of non-irrigated vines from "Carignan N" plot would show fertilisation rate impact previous in this experimental plot. Similarly, the concentration of sodium (Na) in juice was not varied significantly between grapevines irrigated with TWW compared to these irrigated with DW and non-irrigated. The similar behaviour of grape characteristics between treatments is very important to assure grape-growers that the quality of their yields and products would not be modified by supplying treated wastewater to their crops [16].

Wine quality parameters studied [alcohol, $\mathrm{pH}, \mathrm{AV}, \mathrm{TA}$, ion content $(\mathrm{K}, \mathrm{Ca}$, and $\mathrm{Cu})$ in red and white wines, and color intensity, total polyphenol content and anthocyanin concentration in red wine] were mainly influenced by the grape must initial composition, which was determined mostly by grape variety and climatic conditions (data not shown). Moreover, the wines produced would be free from microbiological contamination, such as has been demonstrated during three years of experimentation performing on the same experimental plots [30].

\section{Conclusion}

This study provides scientific and technical knowledge on a strategy of water management with high added value, and highlights the fact that proper handlings of treated wastewater quality and grapevine drip irrigation are essential to reduce environmental and health risks. The results have important practical implications, in both national and international contexts. Ensuring treated wastewater microbiological quality is essential, but without reducing of its nutrients (mainly N, P and $\mathrm{K}$ ). These nutrients would be a valuable input for crop growth and yield, and could reduce the need for inorganic/synthetic fertilizers. The soil's ability to self-cleanse at each rain event would decreases the salinity supplied with treated wastewater, but it will depend on ratio supply-water/rain-water. A sustainable use of treated wastewater over the long term would, however, necessitate a good practice guidelines and an integrated vision of treated wastewater quality, crops, irrigation and post-harvest practices.

This research was supported through a grant from the International Organisation of Vine and Wine (OIV), and executed under the Irri-Alt'Eau Observatory program with the French National Institute for Agricultural Research (UEPR and LBE). This program has benefited from public co-financing: ERDF Funds, Occitanie Region, Bpifrance, Corsica Rhone Mediterranean Water Agency and Grand Narbonne Agglomeration Community, and private: Veolia water, Aquadoc, Gruissan Wine Cellar Cooperative. The authors would like to thank J.-M. Clerc (AD'OCC) for support at the setting up of project, as well as J.-J. Regadera, J. Degroise, J. Cerutti, F. Caumette and F. Robert for their assistance in field work.

\section{References}

[1] V. Lazarova, B. Levine, J. Sack, G. Cirelli, P. Jeffrey, H. Muntau, M. Salgot, F. Brissaud, Water Sci. Technol. 43, 25 (2001)

[2] J. Anderson, Water Sci. Technol.: Water Supply 3, 1 (2003)

[3] M. Elimelech, Water Supply Res. T. 55, 3 (2006) 
[4] FAO Water reports. 38 (2012)

[5] J.C. Durán-Álvarez, B. Jiménez-Cisneros, Environ. Risk Assessment of Soil Contamination 5, 137 (IntechOpen, 2014)

[6] F. Etchebarne, J.-L. Escudier, H. Ojeda, Rev. Enologues 160, 9 (2016)

[7] A.N. Angelakis, M.H.F. Marecos de Monte, L. Bontoux, T. Asano, Water Res. 33, 2201 (1999)

[8] F. Etchebarne, J.-L. Escudier, H. Ojeda, Rev. OE nologues 160, 11 (2016)

[9] M.G. McCarthy, Am. J. Enol. Viticult. 32, 189 (1981)

[10] N. Kretschmer, L. Ribbe, H. Gaese, Technol. Resour. Manage. Develop. 2, 35 (2002)

[11] C. Fausto Cereti, F. Rossini, F. Federici, D. Quaratino, N. Vassilev, M. Fenice, Bioresource Technol. 91, 135 (2004)

[12] G.H. Neilsen, D.S. Stevenson, J.J. Fitzpatrick, Can. J. Plant Sci. 69, 1285 (1989)

[13] N.V. Paranychianakis, S. Aggelides, A.N. Angelakis, Agric. Water Manag. 69, 13 (2004)

[14] E. Weber, S. Grattan, B. Hanson, R.D. Meyer, T. Prichard, L. Schwanki, Tech. Rep. NSD Recycled Water for Vineyard Irrigation (2006)

[15] M.S. Sakellariou-Makrantonaki, I. Kalavrouziotis, D. Giakos, N. Vagenas, Fresenius Environ. Bull. 15, 129 (2006)

[16] L.G. Mendoza-Espinosa, A. Cabello-Pasini, V. Macias-Carranza, W. Daessle-Heuser, M.V. OrozcoBorbon, A.L. Quintanilla-Montoya, Water Sci Technol. 57, 1445 (2008)

[17] M.G. McCarthy, Project SAR 00/7. Final report to Grape and Wine Research and Development Corporation (South Australian Research and Development Institute, Adelaide, 2010)

[18] S. Laurenson, N.S. Bolan, E. Smith, M. McCarthy, Aust. J. Grape. Wine Res. 18, 1 (2012)

[19] D. Acosta-Zamorano, V. Macías-Carranza, L. Mendoza-Espinosa, A. Cabello-Pasini, Agrociencia 47, 767 (2013)

[20] A. Kumar, P. Rengasamy, L. Smith, H. Doan, D. Gonzago, A. Gregg, S. Lath, D. Oats, R. Correll, Sustainable Recycled Winery Water Irrigation based on Treatment Fit for Purpose Approach (Technical report, CSIRO, Australia, 2014)

[21] R.M. Stevens, D.L. Partington, Agric. Water Manag. 122, 39 (2013)

[22] M.C. Buelow, K. Steenwerth, S.J. Parikh, Agric. Water Manag. 152, 277 (2015)

[23] H. Marschner, Mineral nutrition of higher plants, 2nd ed. (Academic Press, London, 1995)

[24] T. Asano, Wastewater reclamation and reuse: Water quality management library (Technomic Publishing Company, Pennsylvania, 1998)

[25] B. Jiménez, P. Drechsel, D. Koné, A. Bahri, L. Raschid-Sally, M. Qadir, Wastewater irrigation and health: Assessing and mitigating risk in low-income countries (Earthscan/IDRC/IWMI, London/Ottawa/Colombo, 2010), p. 3

[26] F. Etchebarne, M. Echegoyen, Y. Sire, J.-L. Escudier, Y. Jaeger, B. Goral, H. Ojeda, Proceeding of 19th GiESCO International Meeting of Viticulture, Pech Rouge - Montpellier, France (Book of full manuscripts, 2015), vol. 1, p. 51
[27] Y. Jaeger, F. Etchebarne, Y. Sire, J.-L. Escudier, H. Ojeda, N. Rampnoux, B. Goral, Proceeding of 19th GiESCO International Meeting of Viticulture, Pech Rouge - Montpellier, France (Book of full manuscripts, 2015), vol. 1, p. 117

[28] F. Etchebarne, Y. Sire, J.-L. Escudier, M. Torrijos, N. Wery, G. Santa-Catalina, D. Patureau-Steyer, Y. Jaeger, B. Goral, N. Rampnoux, H. Ojeda, Proceeding of WINERY 2015: 7th IWA Specialized Conference on Sustainable Viticulture, Winery Wastes \& Agri-industrial Wastewater Management, Stellenbosch, South Africa (Book of abstracts, 2015), p. 16

[29] F. Etchebarne, M. Echegoyen, G. Pereyra, S. VanHouten, Y. Sire, J.-L. Escudier, M. Torrijos, N. Wery, G. Santa-Catalina, D. Patureau, Y. Jaeger, B. Goral, N. Rampnoux, H. Ojeda, Rev. Enologues 161, 12 (2016)

[30] F. Etchebarne, M. Echegoyen, G. Pereyra, S. VanHouten, Y. Sire, J.-L. Escudier, M. Torrijos, N. Wery, G. Santa-Catalina, D. Patureau, Y. Jaeger, B. Goral, N. Rampnoux, H. Ojeda, Proceeding of 20th GiESCO International Meeting Mendoza, Argentina (Book of full manuscripts, 2017), p. 597

[31] B.G. Coombe, Aust. J. Grape Wine Res. 1, 100 (1995)

[32] H. Ojeda, Le Progrès Agri. Viti. 7, 133 (2007)

[33] H. Mabrouk, A. Carbonneau, Le Progrès Agri. Viti. 113, 392 (1996)

[34] P. Galet, Précis de viticulture (Impri. Dehan., 6th ed. Montpellier, France, 1993), p. 339

[35] O. Lohnertz, Proceedings of the International Symposium on Nitrogen in Grapes and Wine (The American Society for Enology and Viticulture: Seattle, Washington, 1991), p. 1

[36] N.V. Paranychianakis, M. Nikolantonakis, Y. Spanakis, A.N. Angelakis, Agric. Water Manag. 81, 185 (2006)

[37] I. Klein, M. Strime, L. Fanberstein, Y. Mani, Vitis 39, 55 (2000)

[38] K. Sakadevan, B.L. Maheshwari, H.J. Bavor, Aust. J. Soil Res. 38, 653 (2000)

[39] K.H. Northcote, Viticulture, resources in Australia (Australian Industrial Publishers: Adelaide, 1992), vol. 1, p. 61

[40] F. Pomares, J. Roca, F.J. Tarazona, M.F. Estale, Processing and Use of Sewage Sludge (D. Reidel Publishing Co., Dordrecht, Holland, 1984), p. 313

[41] B. Jiménez-Cisneros, Water Sci. Technol. 32, 173 (1995)

[42] S.R. Grattan, C.M. Grieve, Sci. Hort. 78, 127 (1998)

[43] J.R.V. Pils, D.A. Laird, V.P. Evangelou, Applied Clay Science (Elsevier, 2007) vol. 35, p. 201

[44] P.A. Rengasamy, Marchuk, Soil Res. 49, 280 (2011)

[45] R.S. Ayers, D.W. Westcot, FAO Irrigation and Drainage Paper 29 (1985)

[46] R.S. Murray, C.D. Grant, The impact of irrigation on soil structure (The National Program for Sustainable Irrigation, Land \& Water Australia, 2007)

[47] B. Bravdo, Y. Hepner, C. Loinger, S. Cohen, H. Tabacman, Am. J. Enol. Viticult. 36, 132 (1985) 